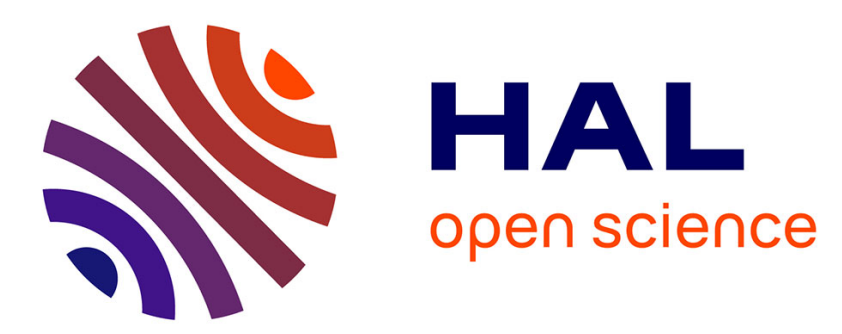

\title{
Time-resolved X-ray absorption spectroelectrochemistry of redox active species in solution
}

Khaled Cheaib, Baptiste Maurice, Tiphaine Mateo, Zakaria Halime, Benedikt Lassalle-Kaiser

\section{- To cite this version:}

Khaled Cheaib, Baptiste Maurice, Tiphaine Mateo, Zakaria Halime, Benedikt Lassalle-Kaiser. Timeresolved X-ray absorption spectroelectrochemistry of redox active species in solution. Journal of Synchrotron Radiation, 2019, 26 (6), pp.1980-1985. 10.1107/S1600577519013614 . hal-02385904

\section{HAL Id: hal-02385904 https://hal.science/hal-02385904}

Submitted on 10 Nov 2020

HAL is a multi-disciplinary open access archive for the deposit and dissemination of scientific research documents, whether they are published or not. The documents may come from teaching and research institutions in France or abroad, or from public or private research centers.
L'archive ouverte pluridisciplinaire HAL, est destinée au dépôt et à la diffusion de documents scientifiques de niveau recherche, publiés ou non, émanant des établissements d'enseignement et de recherche français ou étrangers, des laboratoires publics ou privés. 


\section{ARTICLE IN PRESS - J. Synchrotron Rad.}

JOURNAL OF

SYNCHROTRON

RADIATION

\section{Time-resolved X-ray absorption spectroelectrochemistry of redox active species in solution.}

ISSN 1600-5775

\section{Proof instructions}

Proof corrections should be returned by 21 October 2019. After this period, the Editors reserve the right to publish your article with only the Managing Editor's corrections.

Please

(1) Read these proofs and assess whether any corrections are necessary.

(2) Check that any technical editing queries highlighted in bold underlined text have been answered.

(3) Send corrections by e-mail to tw@iucr.org. Please describe corrections using plain text, where possible, giving the line numbers indicated in the proof. Please do not make corrections to the pdf file electronically and please do not return the pdf file. If no corrections are required please let us know.

To arrange payment for open access, please visit http://scripts.iucr.org/openaccess/?code=hf5386. To purchase printed offprints, please complete the attached order form and return it by e-mail.

\section{Please check the following details for your article}

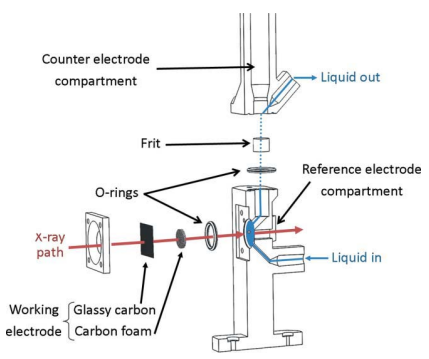

Thumbnail image for contents page
Synopsis: X-ray absorption spectra can be recorded at different points in time during a cyclic voltammetry experiment. This time-resolved X-ray spectroelectrochemistry technique can be used to probe transient species formed at an electrode in solution.

Abbreviated author list: Cheaib, K.; Maurice, B.; Mateo, T.; Halime, Z.; Lassalle-Kaiser, B.

Keywords: time-resolved X-ray absorption spectroscopy; cyclic voltammetry; redox reactions

Copyright: Transfer of copyright received.

\section{How to cite your article in press}

Your article has not yet been assigned page numbers, but may be cited using the doi:

Cheaib, K., Maurice, B., Mateo, T., Halime, Z. \& Lassalle-Kaiser, B. (2020). J. Synchrotron Rad. 27, https://doi.org/ $10.1107 / \mathrm{S} 1600577519013614$.

You will be sent the full citation when your article is published and also given instructions on how to download an electronic reprint of your article. 
JOURNAL OF SYNCHROTRON RADIATION

ISSN 1600-5775

Received 20 May 2019

Accepted 5 October 2019

Edited by S. M. Heald, Argonne National Laboratory, USA

Keywords: time-resolved X-ray absorption spectroscopy; cyclic voltammetry; redox reactions.

Supporting information: this article has supporting information at journals.iucr.org/s

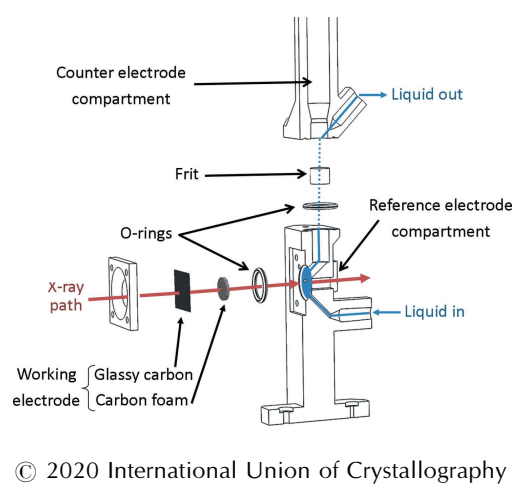

\section{Time-resolved X-ray absorption spectroelectro- chemistry of redox active species in solution.}

\author{
Khaled Cheaib, ${ }^{\mathrm{a}, \mathrm{b}}$ Baptiste Maurice, ${ }^{\mathrm{b}}$ Tiphaine Mateo, ${ }^{\mathrm{b}}$ Zakaria Halime $^{\mathrm{a} *}$ and \\ Benedikt Lassalle-Kaiser ${ }^{\mathrm{b}}$ *
}

anstitut de Chimie Moléculaire et des Matériaux d'Orsay (UMR CNRS 8182), Université Paris-Sud, Batiment 420, Rue du Doyen G. Poitou, 91405 Orsay, France, and ' ${ }^{\mathbf{b}}$ Synchrotron SOLEIL, I'Orme des Merisiers, Saint-Aubin, 91191 Gif-sur-Yvette, France. *Correspondence e-mail: zakaria.halime@u-psud.fr, benedikt.lassalle@synchrotron-soleil.fr

Electrochemistry and electrocatalysis have been receiving increased attention recently due to their crucial contribution to electrical-to-chemical conversion systems. Here the development and operation of a new spectroelectrochemical transmission cell for time-resolved X-ray absorption spectroscopy of solutions is described. X-ray absorption spectra were recorded on the ROCK beamline of SOLEIL under constant and scanning potentials. Spectra were recorded at a frequency of $2 \mathrm{~Hz}$ during a cyclic voltammetry experiment performed on a $20 \mathrm{~m} M$ solution of $\mathrm{Fe}^{\mathrm{III}} \mathrm{Cl}_{3} \cdot 6 \mathrm{H}_{2} \mathrm{O}$ at $20 \mathrm{mV} \mathrm{s}^{-1}$ scanning speed. Spectra with good signal-to-noise ratios were obtained when averaging ten spectra over $5 \mathrm{~s}$, corresponding to a $100 \mathrm{mV}$ potential range. A $90 \%$ conversion rate from $\mathrm{Fe}(\mathrm{III})$ to $\mathrm{Fe}(\mathrm{II})$ was spectroscopically demonstrated in cyclic voltammetry mode.

\section{Introduction}

Electrochemistry is a crucial technique for the study of electron transfer processes that occur between an electrode surface and a redox-active film or solution. It has become more and more popular in the last decade with the advent of solar- (McKone et al., 2014) or electricity-to-fuel (Tatin et al., 2016) devices. Electrolyzers, fuel cells or photoelectrochemical cells all have in common an interaction between an electrode and a catalyst. Electrochemical analysis techniques can provide precious thermodynamic and kinetic information on electrochemical and chemical reactions; however, they do not provide information on the geometric and electronic structure of the catalyst or intermediate species of concern. In order to understand an electrochemical reaction more precisely, complementary information on the local and electronic structure of the redox-active species is very precious. The coupling of X-ray spectroscopies with electrochemical techniques allows gathering of such information while being close to actual operation conditions. Despite difficulties in having regular access to synchrotron radiation X-ray sources, X-ray techniques present several advantages when coupled with electrochemistry. Their penetration depth (which is energydependent) allows the use of a variety of materials and thicknesses, with transmission or back-scattering geometries. It also offers a very broad range of local and electronic information, from the spin and oxidation state (X-ray absorption near-edge spectroscopy, XANES) to the number and distances of the first neighbors (extended X-ray absorption fine structure, EXAFS). Moreover, these pieces of information are element specific, which is crucial when analyzing complex systems with multiple elements involved in redox transformations. 
In situ and operando X-ray absorption spectroelectrochemistry experiments were first developed in the 1980s to study homogeneous stable redox species in solution. For example, Smith et al. (1984) reported an in situ Fe $K$-edge EXAFS study, in which they showed that the $\mathrm{Fe}-\mathrm{C}$ bond increases by $0.03 \AA$ upon transformation from ferrous to ferric cyanide. The technique was widely applied to study the oxidation states and/or the coordination chemistry of stable electrochemically generated metal complexes (Dewald et al., 1986; Antonio et al., 1997; Soderholm et al., 1999; Bae et al., 2001; Levina et al., 2004; Hennig et al., 2005; Milsmann et al., 2006; Takao et al., 2010; Yeo et al., 2012; Best et al., 2016). Operando XAS spectroelectrochemistry later thrived in the last decade concomitantly to the increased interest in energyrelated electrochemical applications such as electrocatalysis (Friebel et al., 2015; Kornienko et al., 2015; Lassalle-Kaiser et al., 2017; Risch et al., 2015; Fabbri et al., 2017), fuel cells (Russell \& Rose, 2004; Scott et al., 2007; Binninger et al., 2016) or batteries (O'Grady, 1996; Giorgetti \& Stievano, 2017). The majority of these energy-related studies were performed on heterogeneous systems with the catalysts deposited as films on the electrode.

The vast majority of XAS spectroelectrochemical experiments described so far were performed with a constant electrochemical potential applied in order to completely convert a solubilized species (homogeneous) or to maintain a material under a particular condition (heterogeneous). Such constant potential experiments are, however, incompatible with the detection and study of short-lived species that can be generated in the vicinity of an electrode during a cyclic voltammetry experiment, but can evolve over time if the potential is kept constant. Determining the structure and properties of these transient species generated during the electrochemical process is of major importance for the elucidation of homogeneous as well as heterogeneous electrochemical reaction mechanisms.

Only a few experiments were carried out using timeresolved XAS spectroelectrochemistry. Nagasaka et al. recently reported on a transmission cell for the in situ coupling of electrochemistry and Fe L-edge XAS (Nagasaka et al., 2013, 2015). In this experiment, multiple Fe $L$-edge XAS spectra were measured at different stationary potentials to cover the potential window of $\mathrm{Fe}(\mathrm{II}) / \mathrm{Fe}(\mathrm{III})$ redox coupling. This cyclic voltammetry-like experiment operates with a pseudo potential scan rate of $0.08 \mathrm{mV} \mathrm{s}^{-1}$ imposed by the modulation of the step potential and the time required to record each XAS spectrum. This approach is clearly too slow to observe transient species formed by an electron transfer from/to an electrode. Fixed-energy X-ray absorption voltammetry (FEXRAV) was recently introduced as a method to circumvent the long acquisition times typically required for an XAS spectrum (Minguzzi et al., 2013; Rondinini et al., 2016; Montegrossi et al., 2017). Although using this technique to collect a XANES or EXAFS spectrum with a good energy resolution is extremely time consuming, it allows for a fast analysis of the oxidation state of a given element at selected potentials and hence opens the door to kinetic analysis. This method was extended to Fe $L$-edge XANES by Nagasaka $\boldsymbol{e t}$ al. (2014) [not in References. 2013 or 2015?] in order to probe the electronic structure of $\mathrm{FeSO}_{4}$ in solution during a cyclic voltammogram. Unfortunately, the setup did not allow a high conversion of the species in solution and the $\mathrm{Fe} L$-edge XANES spectra collected therefore represented a mixture of species.

In this paper, we report on the development of a new spectroelectrochemical cell for the collection of XAS spectra along the course of a cyclic voltammogram. The concept was demonstrated using $\mathrm{Fe}^{\mathrm{III}} \mathrm{Cl}_{3} \cdot 0.6 \mathrm{H}_{2} \mathrm{O} / \mathrm{Fe}^{\mathrm{II}} \mathrm{Cl}_{2}$ as the redox couple in water. Time-resolved XANES at the Fe $K$-edge have been conducted in transmission-mode detection, with a high conversion yield achieved during cyclic voltammetry (CV). A $20 \mathrm{mV} \mathrm{s}^{-1}$ scan rate was used to record cyclic voltammograms while XANES spectra with good signal-to-noise ratios were collected every $5 \mathrm{~s}$, corresponding to a $100 \mathrm{mV}$ potential range. EXAFS spectra could also be collected up to $k=$ $10 \AA^{-1}$.

\section{An electrochemical cell for in situ time-resolved transmission XAS measurements}

An electrochemical cell was designed in order to collect transmission XAS data during a cyclic voltammetry experiment. The main issue lies in the use of a very high surface area electrode in order to convert the whole solution analyzed by the X-rays during a cyclic voltammetry experiment. Fig. 1 describes the design of this cell, with a vertical section of the main part showing the liquid compartment. Photographs of the cell and of its parts can be found in Fig. S1 of the supporting information. The analysis chamber is a cylinder, which is represented by the blue circle in Fig 1 . This chamber has a $5 \mathrm{~mm}$ diameter and can hold a volume varying from $20 \mu \mathrm{l}$ to $40 \mu \mathrm{l}$ depending on its thickness (from $1 \mathrm{~mm}$ to $2 \mathrm{~mm}$ ). The analysis chamber is filled from the bottom to the top to expel

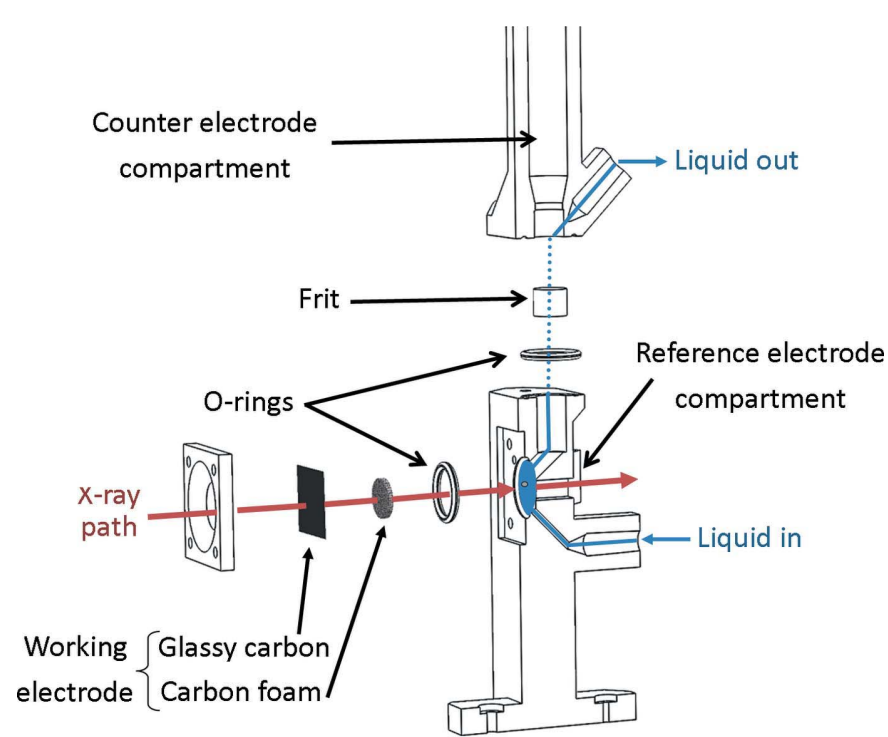

Figure 1

Detailed view of the transmission mode spectroelectrochemical cell developed for time-resolved data collection. 
any air bubbles and the liquid can be circulated to regenerate the sample to be analyzed. The working electrode (WE) consists of a glassy carbon foam which is fitted inside the analysis chamber and is electrically connected by compressing a glassy carbon film $\left(60 \mu \mathrm{m}\right.$ thick and $10 \mathrm{~mm}^{2}$ in size $)$ from the front side (Fig. S1). The back window of the analysis chamber is sealed with a $25 \mu \mathrm{m}$-thick Kapton film. The electrical contact with the WE is ensured by a gold tip inserted from the back of the cell and soldered to a copper wire (Fig. S1). An Ag or Pt wire was inserted from the side of the cell to reach the analysis chamber and used as a pseudo-reference electrode (RE). The counter electrode (CE) is a Pt mesh, housed in a separate compartment connected to the top of the cell through a vycor frit and filled with the electrolyte solution (Fig. S1).

\section{Results and discussion}

\subsection{Electrochemistry}

Fig. 2 shows a cyclic voltammogram of a $20 \mathrm{mM} \mathrm{FeCl} \cdot 6 \mathrm{H}_{2} \mathrm{O}$ aqueous solution in $0.1 \mathrm{M} \mathrm{KCl}$ electrolyte measured in an XAS-spectroelectrochemical cell at $20 \mathrm{mV} \mathrm{s}^{-1}$. The irreversibility of the redox system is due to the inner-sphere nature of the electron transfer in the $\mathrm{Fe}(\mathrm{III}) / \mathrm{Fe}$ (II) coupling in water. Indeed, this type of electron transfer is associated with the adsorption of the chloride ligands of the $\mathrm{FeCl}_{3}$ complex on the glassy carbon electrode, which induces a reorganization of the ligands around the $\mathrm{Fe}$ ion upon reduction of $\mathrm{Fe}$ (III) and reoxidation of $\mathrm{Fe}(\mathrm{II})$, hence the irreversibility of the wave (Tanimoto \& Ichimura, 2013). A comparison between two CVs measured in the XAS-spectroelectrochemical cell and in a conventional electrochemical cell is shown in Fig. S2. The $\mathrm{Fe}$ (III) reduction wave is observed at essentially the same potentials in both electrochemical cells, whereas a significant potential shift $(c a .+500 \mathrm{mV})$ is observed for the $\mathrm{Fe}(\mathrm{II})$ reoxidation wave. This shift is due to the slow electron transfer

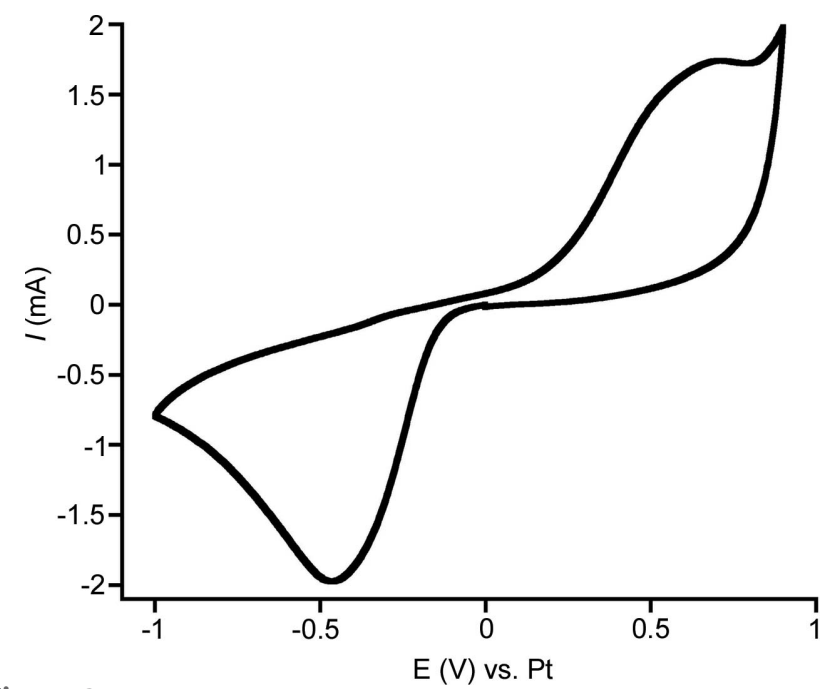

Figure 2

$\mathrm{CV}$ of a $20 \mathrm{mM} \mathrm{FeCl}{ }_{3} \cdot 6 \mathrm{H}_{2} \mathrm{O}$ aqueous solution in $0.1 \mathrm{M} \mathrm{KCl}$ recorded in the XAS-spectroelectrochemical cell at $20 \mathrm{mV} \mathrm{s}^{-1}$ with glassy carbon film and foam as the WE, a Pt mesh as the CE and a Pt wire as the pseudo reference electrode. mentioned above, enhanced by the larger surface area of the WE used in the XAS electrochemical cell. This surface area can be estimated, on the basis of the current intensity, to be 20 times larger $\left(\mathrm{ca} 140 \mathrm{~mm}^{2}\right.$ ) than that of the conventional glassy carbon disk $\left(c a 7 \mathrm{~mm}^{2}\right)$.

\subsection{XAS result}

3.2.1. In situ XAS spectra collection with constant applied potential. Fig. 3 shows the Fe $K$-edge XANES spectra of $\mathrm{Fe}^{\mathrm{III}} \mathrm{Cl}_{3} \cdot 6 \mathrm{H}_{2} \mathrm{O}$ and $\mathrm{Fe}^{\mathrm{II}} \mathrm{Cl}_{2}$ aqueous solutions under an $\mathrm{Ar}$ atmosphere in $0.1 \mathrm{M} \mathrm{KCl}$, recorded in the XAS-spectroelectrochemical cell. The rising edge of the ferrous compound is shifted to lower energies by $5 \mathrm{eV}$ with respect to the ferric one, which is in agreement with reported values (Testemale et al., 2009). This significant shift confirms that the $\mathrm{Fe}^{\mathrm{III}} \mathrm{Cl}_{3} \cdot 6 \mathrm{H}_{2} \mathrm{O} / \mathrm{Fe}^{\mathrm{II}} \mathrm{Cl}_{2}$ redox coupling is a good candidate to evaluate and validate our measurement procedure. Fig. 3 shows the Fe $K$-edge XANES spectra recorded in situ during a constant potential electrolysis performed on an $\mathrm{Fe}^{\mathrm{III}} \mathrm{Cl}_{3}$ solution by applying a reductive potential of $-0.8 \mathrm{~V}$ versus $\mathrm{Pt}$. During the electrochemical transformation, we can clearly observe a gradual edge shift to lower energies, which indicates the progressive formation of the ferrous complex. The presence of isosbestic points at $7130 \mathrm{eV}$ and $7155 \mathrm{eV}$ indicates a direct electron transfer from $\mathrm{Fe}$ (III) to the electrode to yield $\mathrm{Fe}(\mathrm{II})$ during the electrochemical transformation. After $90 \mathrm{~s}$, the current reached a plateau (with a current value close to $0 \mathrm{~A})$, thus indicating the complete conversion of the solution. The proportion of $\mathrm{Fe}(\mathrm{III})$ and $\mathrm{Fe}(\mathrm{II})$ in solution at different time points of the constant potential electrolysis (CPE) was determined by performing linear combination fits using the $\mathrm{Fe}$ $K$-edge XANES reference spectra of $\mathrm{FeCl}_{3} \cdot 6 \mathrm{H}_{2} \mathrm{O}$ and $\mathrm{FeCl}_{2}$

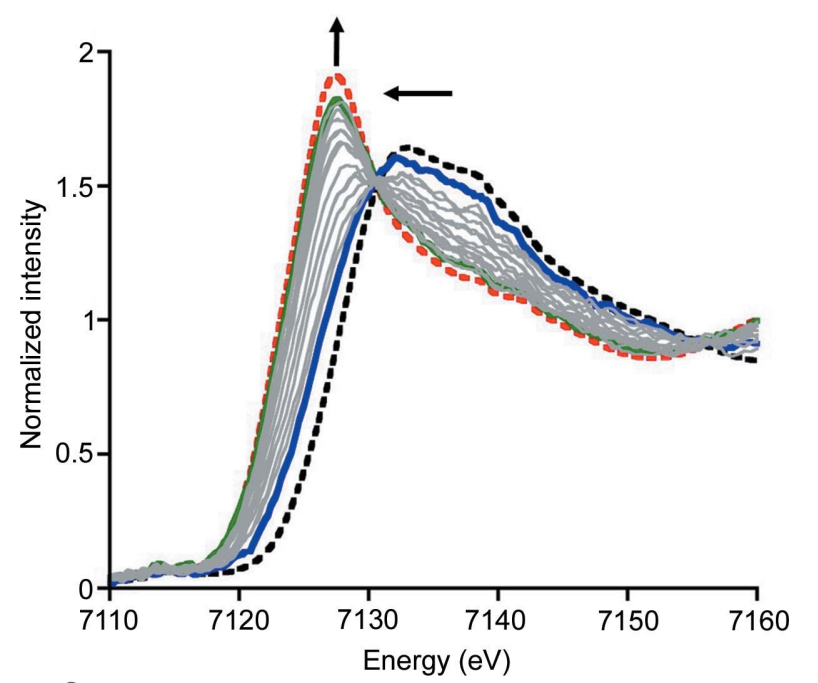

Figure 3

Fe $K$-edge XANES spectra recorded on a $20 \mathrm{~m} M$ aqueous solution of $\mathrm{Fe}^{\mathrm{III}} \mathrm{Cl}_{3} \cdot 6 \mathrm{H}_{2} \mathrm{O}$ (black dashed line) and on a $20 \mathrm{mM}$ aqueous solution of $\mathrm{Fe}^{\mathrm{II}} \mathrm{Cl}_{2}$ (red dashed line) in $0.1 \mathrm{M} \mathrm{KCl}$ electrolyte under an $\mathrm{Ar}$ atmosphere. Time-resolved Fe $K$-edge XANES spectra recorded during the reductive CPE at $-0.8 \mathrm{~V}$ versus $\mathrm{Pt}$ of a $20 \mathrm{~m} M$ aqueous solution of $\mathrm{Fe}^{\mathrm{III}} \mathrm{Cl}_{3} \cdot 6 \mathrm{H}_{2} \mathrm{O}$ in $0.1 \mathrm{M} \mathrm{KCl}$ electrolyte under an $\mathrm{Ar}$ atmosphere starting from $5 \mathrm{~s}$ after the beginning of CPE (blue line) and evolving over time (gray lines) to reach $90 \%$ conversion to $\mathrm{Fe}$ (II) (green line). 
shown in Fig. 3. Using this method of analysis, we determined that $90 \%$ of the $\mathrm{Fe}$ (III) was converted to the corresponding $\mathrm{Fe}$ (II) species at the end of electrolysis (see Fig. S3). In the course of electrolysis from $\mathrm{Fe}(\mathrm{III})$ to $\mathrm{Fe}(\mathrm{II})$, two interruptions were made in the application of a potential in order to check for radiation damage. During these periods of $60 \mathrm{~s}$ and $40 \mathrm{~s}$ without any potential applied (shown as green rectangles in Fig. S3, left), XAS data were still collected. The linear combination fits performed on these data indicated that no change in $\mathrm{Fe}(\mathrm{III}) / \mathrm{Fe}(\mathrm{II})$ proportion was observed during this period of time without any applied potential. This confirms that (i) the reduction of $\mathrm{Fe}$ (III) to $\mathrm{Fe}(\mathrm{II})$ is solely due to the electrochemical reaction at the electrode and (ii) the collection of XAS data for up to $60 \mathrm{~s}$ under these conditions does a perfect agreement is obtained between the kinetics extracted from the chronoamperometry experiment and from the XANES linear combinations (see Fig. S3, right), indicating that the electrochemically transformed solution volume is indeed probed by the X-ray beam.

3.2.2. Potential sweeping in cyclic voltammetry mode. The electrochemical transformations during a complete $\mathrm{CV}$ were not induce any radiation damage. It should also be noted that

monitored by time-resolved XAS. The electrode potential was swept with a scan rate of $20 \mathrm{mV} \mathrm{s}^{-1}$ starting from the open current voltage at $0 \mathrm{~V}$. XAS spectra were measured with a monochromator oscillation of $2 \mathrm{~Hz}$ (only forward scans were recorded) to yield a total of 380 spectra over the complete potential cycle, with an integration time of $250 \mathrm{~ms}$ per spectrum. XANES spectra with a good signal-to-noise ratio were obtained by averaging ten individual spectra, corresponding to a $5 \mathrm{~s}$ time range or a $100 \mathrm{mV}$ potential range. Fig. 4 (top left and right) shows the XANES spectra (after averaging) recorded during the reductive (top left) and oxidative (top right) processes. During the reduction process, the evolution of the spectra shows the formation of the ferrous complex with isosbestic points, as observed in CPE mode (see above). The reverse process is clearly occurring on the re-oxidation step as well.

Fig. 4 (bottom left) shows the proportion profiles of Fe(III) and $\mathrm{Fe}(\mathrm{II})$ obtained from XANES linear combinations performed on the averaged spectra, together with the current as a function of time (blue line). These profiles are in perfect agreement with the theoretical ones expected for an electrochemical Nernstian redox wave, as described by Savéant
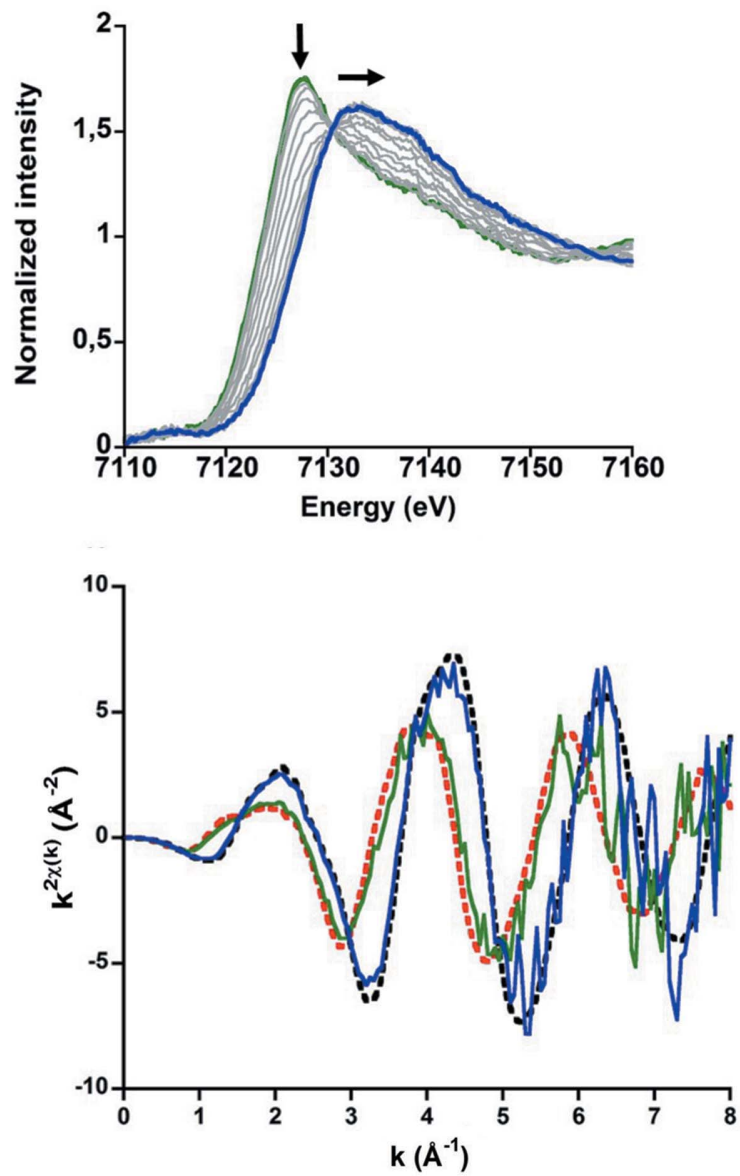

Figure 4
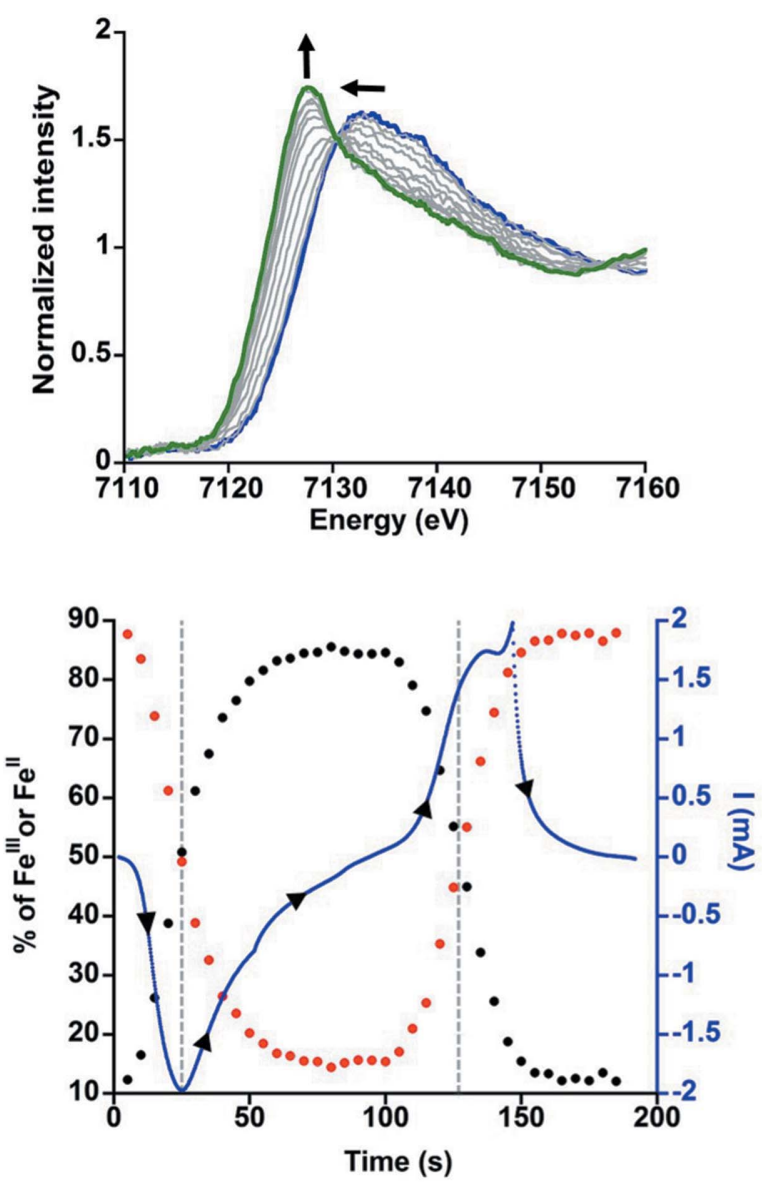

Time-resolved Fe $K$-edge XANES evolution during the reductive process of a $20 \mathrm{~m} M \mathrm{Fe}^{\mathrm{III}} \mathrm{Cl}_{3} \cdot 6 \mathrm{H}_{2} \mathrm{O}$ aqueous solution in $0.1 M \mathrm{KCl}$ under Ar (top left) and its re-oxidation process (top right) along a $20 \mathrm{mV} \mathrm{s}^{-1} \mathrm{CV}$. Evolution of the proportion of $\mathrm{Fe}$ (II) (red dots) and Fe(III) (black dots) determined by XAS during the full cyclic voltammogram (blue line) between $-1 \mathrm{~V}$ and $0.9 \mathrm{~V}$ (bottom left). EXAFS spectra of a $20 \mathrm{~m} M ~^{\mathrm{IIII}} \mathrm{Cl}_{3} \cdot 6 \mathrm{H}_{2} \mathrm{O}$ (black dashed line) and $\mathrm{FeCl}_{2}$ (red dashed line) aqueous solution in $0.1 \mathrm{M} \mathrm{KCl}$ together with spectra collected during a cyclic voltammogram at $100 \mathrm{~s}$ (green line) and $190 \mathrm{~s}$ (blue line) after the beginning of the CV (bottom right). 
(2006). Ratios of 50:50 were observed for the Fe(III) and $\mathrm{Fe}$ (II) species (dashed gray vertical line) when the current reached the cathodic and anodic peak potentials, which is again in agreement with theoretical expectations. At the end of the reduction process, when the potential reaches $-1 \mathrm{~V}$ versus $\mathrm{Pt}$ (after $50 \mathrm{~s}$ ), 86\% of $\mathrm{Fe}$ (III) was converted into $\mathrm{Fe}$ (II) (see Fig. 4 bottom left), while continuing the cycle towards positive potentials leads to a complete regeneration of the initial ferric compound (up to $90 \%$ ) when the potential reaches $0.9 \mathrm{~V}$ versus Pt (after $150 \mathrm{~s}$ ).

EXAFS spectra were also recorded along the cyclic voltammogram up to $k=8$ (Fig. 4 bottom right). Although the $k$-space data clearly show the changes expected for the $\mathrm{FeCl}_{3} \cdot 6 \mathrm{H}_{2} \mathrm{O}$ to $\mathrm{FeCl}_{2}$ conversion, the data quality obtained for a spectrum averaged over $5 \mathrm{~s}$ only allows a Fourier transform analysis for the first neighbors (see Fig. S4). The intensity of the first-shell peak of the time-resolved spectra recorded after $100 \mathrm{~s}$ and $190 \mathrm{~s}$ reproduces very well those observed for the pure $\mathrm{Fe}(\mathrm{II})$ and $\mathrm{Fe}$ (III) species and match with those described in the literature (Inada \& Funahashi, 1999; Inada et al., 1994).

\section{Conclusions}

In summary, investigating the local and electronic structure of redox active molecules in solution using time-resolved X-ray spectroelectrochemistry requires fulfilment of two important criteria: (i) rapid electrochemical transformation with high conversion yield, achieved by using a high-surface-area working electrode; and (ii) a fast data collection technique such as quick-XAS in order to investigate the processes with a good time resolution. In this work, using our newly developed 3D-printed spectroelectrochemical cell, we have demonstrated for the first time the in situ time-resolved XAS monitoring of a dynamic electrochemical process in solution. We have collected data on static liquid solutions, but it should be noted that the measurements can also be performed under liquid circulation. This data collection strategy has advantages (it helps to reduce radiation damage issues) but also drawbacks (electrochemical measurements may be compromised) and should thus be adapted to each specific system. Our efforts are currently focused on the optimization of the cell to improve the data quality while reaching higher potential scan rates. The combination of the cell and data collection methods presented in this paper should be helpful to study the local and electronic structure of redox active, bio-inspired species that can be generated during a cyclic voltammogram, but that are too short-lived to be isolated or generated by constant potential electrolysis. The time resolution we have been able to access so far for a single spectrum ( $5 \mathrm{~s}$ ) only allows for probing of species with lifetimes in the range of seconds. This time resolution could be improved given the capabilities of the ROCK beamline and of the quick-XAS beamlines at other synchrotron facilities. The monochromator frequency used in this study was $2 \mathrm{~Hz}$ (one spectrum in $250 \mathrm{~ms}$ ), but this frequency can be reasonably increased by an order of magnitude. Although a higher time resolution implies a lower signal-to-noise ratio for each single spectrum, it should be pointed out that the collection of multiple spectra is possible, provided that several consecutive CVs can be performed with identical electrochemical features. We are currently using this cell and methodology to study the mechanism of electrocatalytic $\mathrm{CO}_{2}$ reduction by an iron porphyrin catalyst.

\section{Acknowledgements}

Dr Stéphanie Belin is greatly acknowledged for her support during data collection and analysis at the ROCK beamline.

\section{Funding information}

This work is supported by a public grant overseen by the French National Research Agency (ANR) as part of the 'Investissements d'Avenir' program (Labex charmmmat, grant No. ANR-11-LABX-0039).

\section{References}

Antonio, M. R., Soderholm, L. \& Song, I. (1997). J. Appl. Electrochem. 27, 784-792.

Bae, I. T., Tolmachev, Y., Mo, Y., Scherson, D., Scheidt, W. R., Ellison, M. K., Cheng, M.-C., Armstrong, R. S. \& Lay, P. A. (2001). Inorg. Chem. 40, 3256-3258.

Best, S. P., Levina, A., Glover, C., Johannessen, B., Kappen, P. \& Lay, P. A. (2016). J. Synchrotron Rad. 23, 743-750.

Binninger, T., Fabbri, E., Patru, A., Garganourakis, M., Han, J., Abbott, D. F., Sereda, O., Kötz, R., Menzel, A., Nachtegaal, M. \& Schmidt, T. J. (2016). J. Electrochem. Soc. 163, H906-H912.

Dewald, H. D., Watkins, J. W., Elder, R. C. \& Heineman, W. R. (1986). Anal. Chem. 58, 2968-2975.

Fabbri, E., Nachtegaal, M., Binninger, T., Cheng, X., Kim, B.-J., Durst, J., Bozza, F., Graule, T., Schäublin, R., Wiles, L., Pertoso, M., Danilovic, N., Ayers, K. E. \& Schmidt, T. J. (2017). Nat. Mater. 16, 925-931.

Friebel, D., Louie, M. W., Bajdich, M., Sanwald, K. E., Cai, Y., Wise, A. M., Cheng, M.-J., Sokaras, D., Weng, T.-C., Alonso-Mori, R., Davis, R. C., Bargar, J. R., Nørskov, J. K., Nilsson, A. \& Bell, A. T. (2015). J. Am. Chem. Soc. 137, 1305-1313.

Giorgetti, M. \& Stievano, L. (2017). X-ray Characterization of Nanostructured Energy Materials by Synchrotron Radiation, edited by M. Khodaei \& L. Petaccia, pp. 51-75. Rijeka: InTech.

Hennig, C., Tutschku, J., Rossberg, A., Bernhard, G. \& Scheinost, A. C. (2005). Inorg. Chem. 44, 6655-6661.

Inada \& Funahashi (1999). [Please provide the full reference.]

Inada et al. (1994). [Please provide the full reference.]

Kornienko, N., Zhao, Y., Kley, C. S., Zhu, C., Kim, D., Lin, S., Chang, C. J., Yaghi, O. M. \& Yang, P. (2015). J. Am. Chem. Soc. 137, 1412914135.

Lassalle-Kaiser, B., Gul, S., Kern, J., Yachandra, V. K. \& Yano, J. (2017). J. Electron Spectrosc. Relat. Phenom. 221, 18-27.

Levina, A., Foran, G. J., Pattison, D. I. \& Lay, P. A. (2004). Angew. Chem. Int. Ed. 43, 462-465.

McKone, J. R., Lewis, N. S. \& Gray, H. B. (2014). Chem. Mater. 26, 407-414.

Milsmann, C., Levina, A., Harris, H. H., Foran, G. J., Turner, P. \& Lay, P. A. (2006). Inorg. Chem. 45, 4743-4754.

Minguzzi, A., Lugaresi, O., Locatelli, C., Rondinini, S., D'Acapito, F., Achilli, E. \& Ghigna, P. (2013). Anal. Chem. 85, 7009-7013.

Montegrossi, G., Giaccherini, A., Berretti, E., Benedetto, F. D., Innocenti, M., d'Acapito, F. \& Lavacchi, A. (2017). J. Electrochem. Soc. 164, E3690-E3695.

Nagasaka et al. (2014). [Please provide the full reference.] 
Nagasaka, M., Yuzawa, H., Horigome, T., Hitchcock, A. P. \& Kosugi, N. (2013). J. Phys. Chem. C, 117, 16343-16348.

Nagasaka, M., Yuzawa, H. \& Kosugi, N. (2015). J. Electron Spectrosc. Relat. Phenom. 200, 293-310.

O'Grady, W. E. (1996). J. Electrochem. Soc. 143, 1613.

Risch, M., Ringleb, F., Kohlhoff, M., Bogdanoff, P., Chernev, P., Zaharieva, I. \& Dau, H. (2015). Energy Environ. Sci. 8, 661-674.

Rondinini, S., Lugaresi, O., Achilli, E., Locatelli, C., Minguzzi, A., Vertova, A., Ghigna, P. \& Comninellis, C. (2016). J. Electroanal. Chem. 766, 71-77.

Russell, A. E. \& Rose, A. (2004). Chem. Rev. 104, 4613-4635.

Savéant, J. M. (2006). Elements of Molecular and Biomolecular Electrochemistry: an Electrochemical Approach to Electron Transfer Chemistry. Hoboken, NJ: Wiley-Interscience.
Scott, F. J., Roth, C. \& Ramaker, D. E. (2007). J. Phys. Chem. C, 111, 11403. [Correct?]

Smith et al. (1984). [Please provide the full reference.]

Soderholm, L., Antonio, M. R., Williams, C. \& Wasserman, S. R. (1999). Anal. Chem. 71, 4622-4628.

Takao, K., Takao, S., Scheinost, A. C., Bernhard, G. \& Hennig, C. (2010). Inorg. Chim. Acta, 363, 802-806.

Tanimoto, S. \& Ichimura, A. (2013). J. Chem. Educ. 90, 778-781.

Tatin, A., Bonin, J. \& Robert, M. (2016). ACS Energy Lett. 1, 1062 1064.

Testemale et al. (2009). [Please provide the full reference.]

Yeo, J., Cheah, M. H., Bondin, M. I. \& Best, S. P. (2012). Aust. J. Chem. 65, 241. 
ISSN: $1600-5775$

\section{YOU WILL AUTOMATICALLY BE SENT DETAILS OF HOW TO DOWNLOAD \\ AN ELECTRONIC REPRINT OF YOUR PAPER, FREE OF CHARGE. PRINTED REPRINTS MAY BE PURCHASED USING THIS FORM.}

Please scan your order and send to tw@iucr.org

INTERNATIONAL UNION OF CRYSTALLOGRAPHY

5 Abbey Square

Article No.: S191361-HF5386

Chester $\mathrm{CH} 12 \mathrm{HU}$, England.

VAT No. GB 161903476

Title of article Time-resolved X-ray absorption spectroelectrochemistry of redox active species in solution.

Name Benedikt Lassalle-Kaiser

Address Synchrotron SOLEIL, l'Orme des Merisiers, Saint-Aubin, 91191 Gif-sur-Yvette, France

E-mail address (for electronic reprints) benedikt.lassalle@synchrotron-soleil.fr

\section{OPEN ACCESS}

IUCr journals offer authors the chance to make their articles open access on Crystallography Journals Online. If you wish to make your article open access please go to https://scripts.iucr.org/openaccess/?code=HF5386

The charge for making an article open access is from 1400 United States dollars (for full details see https://journals.iucr.org/s/services/openaccess.html). For authors in European Union countries, VAT will be added to the open-access charge.

\section{DIGITAL PRINTED REPRINTS}

I wish to order . . . . . . paid reprints

These reprints will be sent to the address given above. If the above address or e-mail address is not correct, please indicate an alternative:

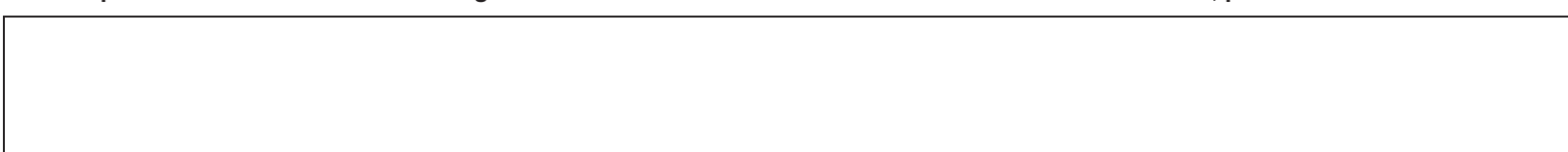

\section{PAYMENT (REPRINTS ONLY)}

Charge for reprints . . . . . . USD

An official purchase order made out to INTERNATIONAL UNION OF CRYSTALLOGRAPHY $\square$ is enclosed $\square$ will follow

Purchase order No

\section{Please invoice me}

I wish to pay by credit card

EU authors only: VAT No:

\begin{tabular}{l|l} 
Date & Signature
\end{tabular}




\section{OPEN ACCESS}

The charge for making an article open access is from 1400 United States dollars (for full details see https://journals.iucr.org/s/services/openaccess.html). For authors in European Union countries, VAT will be added to the open-access charge.

\section{DIGITAL PRINTED REPRINTS}

An electronic reprint is supplied free of charge.

Printed reprints without limit of number may be purchased at the prices given in the table below. The requirements of all joint authors, if any, and of their laboratories should be included in a single order, specifically ordered on the form overleaf. All orders for reprints must be submitted promptly.

Prices for reprints are given below in United States dollars and include postage.

\begin{tabular}{|c|c|c|c|c|c|}
\hline & \multicolumn{5}{|c|}{ Size of paper (in printed pages) } \\
\hline Number of reprints required & $1-2$ & $3-4$ & $5-8$ & $9-16$ & Additional 8's \\
\hline 50 & 184 & 268 & 372 & 560 & 246 \\
\hline 100 & 278 & 402 & 556 & 842 & 370 \\
\hline 150 & 368 & 534 & 740 & 1122 & 490 \\
\hline 200 & 456 & 664 & 920 & 1400 & 610 \\
\hline Additional 50's & 86 & 128 & 178 & 276 & 116 \\
\hline
\end{tabular}

\section{PAYMENT AND ORDERING}

Open-access fees should be paid at https://scripts.iucr.org/openaccess/?code=HF5386

Official purchase orders should be made out to INTERNATIONAL UNION OF CRYSTALLOGRAPHY.

Orders should be returned by email to tw@iucr.org

\section{ENQUIRIES}

Enquiries concerning reprints should be sent to support@iucr.org. 